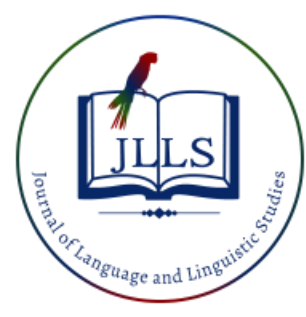

Available online at www.jlls.org

JOURNAL OF LANGUAGE AND LINGUISTIC STUDIES

ISSN: $1305-578 \mathrm{X}$

Journal of Language and Linguistic Studies, 16(4), 1760-1773; 2020

\title{
Non-native speakers' attitudes towards the use of short Arabic stories in language classes
}

\author{
Omran Ahmad Musleh ${ }^{\mathrm{a}}$ (iD), Mohamed Abdelrahman Ibrahim b iD, \\ Abdel Rahman Mitib Altakhaineh ${ }^{\mathrm{c}} 1$ (ID \\ ${ }^{a}$ Al Ain University, Al Ain, United Arab Emirates \\ ${ }^{b}$ IIUM, Selangor, Malaysia \\ APA Citation: \\ ${ }^{b}$ The University of Jordan, Amman, Jordan
}

Musleh O. A., Ibrahim, M. A., Altakhaineh, A. R.M. (2020). Non-native speakers' attitudes towards the use of short Arabic stories in language classes. Journal of Language and Linguistic Studies, 16(4), 1760-1773.

Submission Date: 29/06/2020

Acceptance Date: 17/10/2020

\begin{abstract}
This study aims to investigate the attitudes of non-Arabic students towards reading short stories in Arabic at universities in Malaysia, with a focus on three variables: the students' university, gender, and mother tongue. A mixed-methods approach was employed, using a questionnaire and semi-structured focus group discussion with 58 participants. The study found that the students had positive attitudes toward reading short stories. There were no statistically significant differences between the participants' attitudes based on type of university, gender, and mother tongue. With respect to the types of short stories students prefer, comic stories were read most frequently by students. Finally, students also found it very encouraging and supporting to use short stories to enhance their Arabic language skills. The study concludes with some recommendations for further research.
\end{abstract}

(C) 2020 JLLS and the Authors - Published by JLLS.

Keywords: language teaching, short Arabic stories, Arabic, Malaysia

\section{Introduction}

Due to its universality across cultures, literature has long been integrated with language learning experiences. Indeed, Heath (1996, p. 776) believes that "Literature has no rival in its power to create natural repetition, reflection on language and how it works, and attention to audience response on the part of learners". As a literary genre, stories can be found across cultures and, for this reason, they are a powerful educational tool (Ellis, 2000) in the teaching and learning of second/foreign languages (L2) for non-native speakers (NNSs). For example, they can improve intercultural communicative competence (Rezaei \& Naghibian, 2018) and collocations (Mohammadnejad, 2018), inter alia. Hence, according to Rodrigo et al. (2014), the integration of literature into L2 learning can possibly establish a learning environment which will have a low affective filter and offer comprehensible input.

\footnotetext{
${ }^{1}$ Corresponding author.

E-mail address: a.altakhaineh@ju.edu.jo
} 
Students' attitudes toward reading are an important factor in their willingness to read voluntarily. However, while studies have shown that pre-school children have a positive attitude toward reading, during the primary stage, a negative trend towards reading can occur (Shapiro, 1979). Thus, it is very important to study learner attitudes towards reading stories to aid curriculum design. These attitudes toward reading are influenced by different factors, such as student perceptions and reading abilities, as well as gender, intelligence and socioeconomic status (Alexander \& Filler, 1976); they may also be influenced by parental, teacher, and peer attitudes. Moreover, students tend to have a positive attitude towards activities, tasks, and texts which they find interesting, but avoid those which they find dull or difficult (Salem, 1996). Ghazali (2008) investigated student attitudes towards reading short stories and found that short stories were the most popular genre of literature. The majority of the participants (80\%) showed positive attitudes towards reading short stories because of their length and being less time consuming. Consequently, this helps the students to be committed and take part in in co-curricular activities and do their assignments. Based on the results of interviews, the sampled students agreed that the language is manageable when the plots are interesting and fast-paced, stating that it was like watching a film.

Attitudes are generally influenced by those around us. Parents who enjoy reading or who set priorities for literacy ability are more likely to give these attitudes to their children. Also, when teachers provide appropriate instructions, this often helps to develop positive attitudes towards reading, but when teachers set difficult tasks or boring books, or do not provide opportunities for recreational reading, they can generate negative attitudes towards reading (Salem, 1996, pp. 83-84). However, successful attempts to improve attitudes to reading are not necessarily associated with high-level literacy achievements (Alexander \& Filler, 1976) as attitudes can be unpredictable. Nevertheless, if reading meets a reader's needs, normally a positive attitude towards it will be present (Al-Nassar, Salem \& Abu Hashem, 2006). In their study on the difficulties faced by non-Arabic speakers at the Language Centre of the International Islamic University in Malaysia, Musleh and Ahmed (2010) pointed out the syllabuses have difficulty focusing on grammar, writing, and reading compared to listening and speaking. Other problems were apparent with the Arabic language textbooks used, as these dealt with basic subjects at various levels, and there was a lack of variation in topic since the texts focused on ancient Arab culture, such as Arabic proverbs and stories. There was also a shortage of other reading sources such as simplified books and newspapers. Laine (1997) suggests that teaching short stories in a foreign language to unmotivated children can have a positive impact on their attitude to learning that language.

This study, therefore, investigates non-Arabic speakers' attitudes to reading short stories, at two universities in Malaysia -the International Islamic University and Al Madinah International University -to improve understanding of what motivates students to read to enhance their Arabic language abilities. This research adopts the following questions in relation to enhancing students' Arabic language skills:

1. What attitudes do non-Arabic students have to reading short Arabic stories?

2. Does university, gender, or L1 play a role in affecting non-Arabic students' attitudes to reading short Arabic stories?

3. What types of short stories do non-Arabic students prefer reading?

\subsection{General background}

\subsubsection{Literature on teaching second language}

Several researchers (Hess, 2006; Dornyei, 2005; Wang \& Guthrie, 2004; Morrow, 2004) studied the significance of using literature inside the classroom. For example, Dornyei (2005) pointed out that using literature in the classroom can create a generally positive motivational climate, and, in turn, enhance the motivation to learn a language. As far as L2 learning is concerned, as argued by Wang and Guthrie (2004), learners can increase their vocabulary, and improve their reading comprehension skills (Holden, 
2003). Furthermore, Krashen (2004) suggested that literature makes the learning process more enjoyable through providing L2 learners with texts that are both pleasurable and comprehensible. Indeed, Kim (2004) indicated that such texts can impact positively on reading skills in the L2. As a result, this positive attitude seems to make L2 learners independent readers and that has positive implications for language acquisition.

Beck and McKeown (2001) suggested that literature is a good way of learning vocabulary, since vocabulary activities that are directly delivered can increase learners' vocabulary repertoires. Similarly, Kuhn and Stahl (1998) and Dixon-Krauss (2002) reviewed studies investigating how literary texts can have an influence on vocabulary development; the researchers concluded that incidental learning was responsible for the vast majority of words that were learned as opposed to direct instruction. These conclusions were later supported by Altakhaineh and Zibin (2017), who found out that incidental learning possibly had a significant effect on acquiring English prefixes and suffixes through reading comprehension exercises. Finally, Nash and Snowling (2006) recommended the use of a contextual approach to instruction since it results in remarkable increase in vocabulary than lessons that focused on learning definitions of words.

\subsubsection{Using Stories in Teaching and Learning}

The two most common approaches which use stories in teaching and learning are the story grammar and reader response approaches. The former can be defined as the system of rules employed for providing a description for the story's parts, the way they are arranged and how they are related to each other, i.e. the internal structure of the story. According to Amer (2012), a story may consist of many parts, including characters, setting, problem, action and resolution. The final part is the most important one as it gives learners the opportunity to react to the text through expressing their opinions and feelings. In this way, the reading process can be viewed as an interaction between the reader and text; during which the readers together with their beliefs, experiences and values interact with the text, and as a result its meaning is determined (Ali, 1994).

As far as language learning and teaching is concerned, through stories individuals can construct meaning to the world that surrounds them. The more stories individuals are acquainted with, the greater the realization of their individuality will be, or, in other words, stories help people to determine their values, needs, dreams and fears. Undoubtedly, stories and storytelling are beneficial in ELT. To be effective, teaching materials should intrinsically motivate pupils, capture their attention, attract them, and meet their proficiency and academic levels; for this reason, students are always encouraged to read more stories for pleasure, so that they do not become bored or frustrated with other language learning features. This is especially true if they are failing to meet their potential in terms of vocabulary and sentence structure, etc. This idea is supported by İnal and Cakir (2014), who stated that carefully selected stories promote student motivation and facilitate learning. For example, Biemiller and Boote (2006) found that youngsters can acquire advanced and sophisticated vocabulary through repeatedly reading stories. Baker and Greene (1977) believe that the significance of storytelling relies not only in developing better awareness, and a sense of mystery and joy, but also in how they can lead the reader to respect life.

Two well-known advantages of using stories are, first, that students become more passionate and enjoy learning about the world and language spontaneously; this is similar to how L1 acquisition works when children listen to stories told by grandparents (İnal \& Cakir, 2014). Bafile (2003) believes that story-telling and using stories to teach are effective because they give pupils meaningful contexts in which to see and hear vocabulary. It is widely reported that stories provide learners with opportunities to infer the meaning of new words, and so it is evident that stories contribute to better vocabulary acquisition, either incidentally or unintentionally (İnal, H \& Cakir, 2014). As certain language patterns, structures, and words are repeated in stories, student learning is enhanced as they are exposed to contexts 
they know. Storytelling is an effective teaching instrument that involves many vocabulary teaching techniques which make learning more appealing (Griva, 2007). Dolma and Boonprasitt (2016) found that the vocabulary of seventh grade Bhutanese students developed through the use of a vocabulary selfcollection strategy when reading short stories. Stories help readers to become active and influence their ability to anticipate and predict. In turn, this can result in better recognition of new language patterns, words and phrases in the form of dialogue between characters. This dialogue helps the readers/listeners to infer the meanings of words from their contexts, and can also encourage learners to use the words they have learned, particularly ESL students. The fact that stories are useful for EFL learners is undeniable, as the new words the learners absorb can develop their speaking and writing skills. The second well known advantage of using short stories in teaching is that it draws EFL learners' attention, as learners are introduced to new cultures, values, and lives (Blachowicz \& Fisher, 2004).

\subsubsection{Benefits of short stories}

Several researchers (Sage, 1987; Collie \& Slater, 1991) have listed the advantages for language teachers of using short stories: first, stories can be completely read and discussed in one or two classes due to their practical length; second, foreign language learners may not find them very demanding; third, they can be used for both individual and team work; fourth, they provide a wide range of interests and tastes (e.g. different stories can be selected by a teacher); and, they are suitable for all ages and all language proficiency levels.

Sage (1987) pointed out that a good story is a joy, and consequently helps to provide pleasure and develop knowledge in NNSs; both of them are equally important. The majority of stories, both those that focus on serious or comic matters, are fun to read and discuss; however, short stories could be found easier by students in comparison with other literary genres. This is especially important given that some students find reading tedious and it is increasingly difficult to motivate them, particularly when it comes to literary texts in the EFL/ESL classroom. Short stories therefore offer a solution for teachers of foreign languages, to help the reader/student remain focused on the content, plot and language in the story (Tevdovska, 2016).

The use of short-stories in the L2 classroom also offers opportunities for integration with other language skills. Several studies (Dixon-Krauss, 2002; Blachowicz \& Fisher, 2004; Dillard, 2005) focusing on vocabulary have shown that using short stories can increase word usage compared with word-list instruction. That is, the use of short stories in EFL helps to develop and enrich students' vocabulary. Short stories are also a good context for teaching grammar. For example, Lihanda and Agufana (2017) found that although few of their sample of teachers used short stories to teach Kiswahili grammar, the teachers had a positive attitude towards their use, and the study recommended that teachers should use them for effective Kiswahili grammar teaching. The culture load found in storytelling can be regarded as another advantage of using short stories. This load refers to the relation between language and culture as well as the amount of cultural knowledge needed to understand meaning and thus enable students to take part in an activity (Meyer, 2000). Furthermore, the use of short stories is also regarded as an interesting way of motivating EFL learners to learn more, not only by remembering words but also exposing learners to the culture, moral values, and other elements of the story. Above all, it can improve reading comprehension. Therefore, the use of short stories should be given preference when teaching, to develop and enrich the vocabulary of EFL learners (Al-Dersi, 2013).

\subsubsection{Language attitudes towards short stories}

It is very clear that using stories in L2 teaching can play a major role in learning process, and so studying learner attitudes toward reading short stories is key. In this regard, Montano and Kasprzyk (2008, p. 71) stated that: 
Attitude is determined by the individual's beliefs about outcomes or attributes of performing the behavior (behavioral beliefs), weighted by evaluations of those outcomes or attributes. Thus, a person who holds strong beliefs that positively valued outcomes will result from performing the behavior will have a positive attitude toward the behavior. Conversely, a person who holds strong beliefs that negatively valued outcomes will result from the behavior will have a negative attitude.

In a similar vein, Reid (2003) and Visser (2008) concur with Montano and Kasprzyk (2008), stating that attitude is closely linked to study and an essential factor influencing language performance. This is because the psychological and social aspects of language learning primarily depend on the learners' motivation and attitude to learning the target language (Padwick, 2010). De Bot et al. (2005) assert that language teachers, researchers, and students should acknowledge that high motivation and a positive attitude facilitate L2 learning. Needless to say, if a learner has no interest in acquiring the target language, they will have a negative attitude and be unmotivated to learn it. Thus, a learner's attitude should be considered part of language learning, as it may influence their performance in acquiring the target language (Zainol Abidin \& Mohammadi \& Alzwari, 2012).

\section{Method}

\subsection{Participants}

The research samples at the IIUM Language Centre and MEDIU were purposefully selected for students studying at level six and four, respectively. Both sets of students were completing the last level in Arabic language in the second semester of 2018/2019. The sample sizes were 58 for IIUM and 70 for MEDIU, making a total of 128 students.

\subsection{Data collection and analysis}

The quantitative approach was used, modifying the 18-item questionnaire of Al-Nassar et al. (2006) to measure students' attitudes to reading short stories in Arabic. The 18 items were distributed across three dimensions, as: the benefits of reading stories in life in general and language learning in particular; visiting the library, and buying and exchanging stories; and, reading stories and feelings of pleasure in reading them. A qualitative approach was also employed through focus group discussions with the 58 students. They were asked direct questions to identify the type of story they liked. Both the questionnaire and focus groups were conducted in the second semester of 2018/2019.

Descriptive statistics were used to measure the learners' attitudes towards reading and learning Arabic through short stories. Student responses were categorized as disagreement, neutral or in agreement and the frequency of their responses was used to indicate their attitude. An Independent Sample T-test was also conducted to examine the statistical differences between the three questionnaire dimensions and the three research variables (university, gender, and reading short stories in the mother tongue). Mean, standard deviation, and $\mathrm{t}$ and $p$-values were calculated to determine any statistically significant differences in the sample referring to the three variables. Furthermore, to provide answers to question three, the focus group of 58 students was asked which type of story they preferred to read in Arabic. The answers were collected and calculated manually to identify the frequencies of each type of story. 


\section{Results and Discussion}

Tables 1-3 present the descriptive statistics analysis of the three main dimensions.

\subsection{Findings on the first dimension}

Table 1 shows the frequencies for the items that measured the benefits of reading stories in general life and learning a language in particular.

Table 1. Descriptive statistics of the first dimension

\begin{tabular}{llll}
\hline $\begin{array}{l}\text { Benefits of reading stories in general life and learning a } \\
\text { language in particular }\end{array}$ & Disagreement & Neutral & Agreement \\
\hline I think reading stories helps me to understand life & 5 & 2 & 121 \\
I like reading stories because it helps me learn Arabic & 2 & 14 & 112 \\
Reading stories teaches me new information & 1 & 3 & 124 \\
I like reading stories because it helps to improve my language & 2 & 3 & 122 \\
skills & 10 & 12 & 106 \\
Reading stories is necessary for success in life & 10 & \\
\hline
\end{tabular}

The table above shows that the majority of the students thought that reading stories would help them to understand life ( $n=121)$, liked reading stories because it helped them to learn Arabic $(n=112)$, agreed that reading stories taught them new information $(n=124)$, liked reading stories because it helped to improve their language skills $(\mathrm{n}=122)$, and agreed that reading stories is necessary for success in life $(n=106)$. In general, the frequencies show that the majority of the students agreed that reading stories would benefit their life and language learning. There are two possible reasons for this finding. First, short stories represent other people's experiences, opinions, culture, traditions, feelings, and life events, which enriches learners' thinking, experience, feelings, and morals. Second, short stories deepen the culture of the language, because it uses common and familiar words and language.

The results on the first dimension (see Table 1) revealed that the majority of the students agreed that reading stories would help them to learn Arabic. These results concur with the findings of Inal and Cakir (2014) which indicated that short stories help us to make sense of our world. The more stories we study, the more we realize our individuality in significant ways. Through stories, people express their values, fears, hopes, and dreams. Similarly, Al-Dersi (2013) suggested that the use of short-story is also regarded as an interesting method which can attract EFL learners to learn more, not only remembering each words but also the culture, moral values. It is confirmed that one of the main advantages of using stories is to put the students in a varied and enjoyable context. In this way, they have a chance to learn about the world and language at the same time, as it occurs in the first language acquisition (Inal \& Cakir, 2014). According to Blachowicz and Fisher (2004), short stories introduce new vocabulary in the form of dialogue, and so ESL learners tend to remember the meanings of new phrases from the stories. This is necessary in mastering a foreign language. With regard to the benefit of reading stories when learning a language, it can be argued that stories promote vocabulary acquisition, grammar knowledge, and reading comprehension, not only because they have rich language and meaning, but also because of their varied syntax and the use of familiar words which are easy to understand. In terms of learning vocabulary, the findings of Dolma and Boonprasitt (2016) supported the results above in the sense that the use of the self-collection vocabulary strategy in short story reading significantly enhanced the vocabulary of seventh grade Bhutanese students. As well as vocabulary, stories are also known to 
enhance grammar study (Lihanda \& Agufana, 2017) and reading comprehension and, therefore, they should be given preference in teaching (Al-Dersi, 2013).

\subsection{Findings on the second dimension}

Table 2 presents the frequencies which measured visiting the library and buying and exchanging stories.

Table 2. Descriptive statistics of the second dimension

\begin{tabular}{llll}
\hline Visiting the library and buying and exchanging stories & Disagreement & Neutral & Agreement \\
\hline I like to exchange stories with my friends & 5 & 20 & 103 \\
Spending money to buy stories is a great advantage & 8 & 17 & 103 \\
I feel happy if I am given a story book as a gift & 5 & 10 & 112 \\
I like visiting bookshops to buy stories & 14 & 16 & 97 \\
I wish I had my own library of story books & 7 & 18 & 103 \\
\hline
\end{tabular}

Table 2 shows the responses to the five items measuring their visit to the library and buying and exchanging stories. All items received an overwhelmingly positive response from the students, with 103 students who liked to exchange stories with their friends and believing that spending money to buy stories was a great advantage; they also wished that they had their own library of story books, and 112 students felt happy if they were given a story book as a gift. Most of the students liked visiting a bookshop to buy stories ( $\mathrm{n}=97$ ), and they generally felt positive towards visiting the library and buying and exchanging stories.

From these results, the students appeared to have positive attitudes to reading short stories due to their short length and because they can be read and finished fast. They also liked the consistency of plot events, and how the accompanying pictures made reading easy and interesting for learners. The students were aware of how short stories are cheaper compared to other printed books, and thus they liked buying and exchanging stories. Kim (2004) indicated that a combination of pleasurable and comprehensible texts helps learners to develop a positive attitude towards reading in the L2, and so this positive attitudinal change is likely to lead to more independent reading, which is in turn beneficial for language acquisition.

\subsection{Findings on the third dimension}

Table 3 shows the frequencies measuring the dimension of reading stories and feelings of pleasure in them.

Table 3. Descriptive statistics of the third dimension

\begin{tabular}{llll}
\hline Reading stories and feelings of pleasure in reading them & Disagreement & Neutral & Agreement \\
\hline Reading stories is one of the best things to do when I am free & 13 & 19 & 96 \\
I am happy if a time is allocated to read stories & 4 & 16 & 107 \\
I miss reading stories when I stop for a while & 15 & 34 & 78 \\
I like reading stories & 5 & 12 & 111 \\
Reading stories is interesting to me & 4 & 9 & 114 \\
I feel relaxed when I read a story & 4 & 20 & 104 \\
I feel sad for friends who don't read stories & 25 & 43 & 60 \\
Reading stories is one of my best hobbies & 17 & 23 & 87 \\
\hline
\end{tabular}


According to the results in Table 3,114 students thought that reading stories is interesting, 111 students liked reading stories, 107 students were happy with time being allocated for reading, and 104 students felt relaxed when they read a story. Regarding whether reading stories was one of the best things to do when free, 96 students agreed with this statement, and 87 students agreed that reading stories was one of their best hobbies. Just over half $(n=78)$ of the students missed reading when they stopped for a while, but only 60 students felt sad for friends who did not read stories. These results show that most of the respondents had positive opinions about reading stories and felt pleasure in doing so.

The results on the third dimension suggesting that reading stories was pleasurable for these students support those from the first two dimensions regarding the role of stories in language acquisition, and the features of stories generally and short stories in particular. Examples of these include their limited length, consistency, and exploration of other people's lives, experiences, feelings, and culture. In line with these findings, Ghazali (2008) found that $80 \%$ of their study's participants expressed positive attitudes towards reading short stories, stating that they are easy to read as they are not lengthy and are less time consuming, which, in turn, helps homework completion and participation in co-curricular activities. In a similar vein, Kim (2004) indicated that a combination of pleasurable and comprehensible texts helps learners to develop a positive attitude towards reading in the L2. Indeed, all these results may also be linked to the fact that reading short stories can change the daily routine of life and reduce stress (see for more details Lewis, 2009).

\subsection{University differences in the three constructs}

The results of the independent samples t-test showed no statistically significant differences between the universities for the three constructs, namely: the benefits of reading stories in general life and learning a language in particular $(\mathrm{t}(125)=-1.10, \mathrm{p}=0.27)$; visiting the library and buying and exchanging stories $(\mathrm{t}(124)=-0.97, \mathrm{p}=0.33)$; and, reading stories and feeling pleasure in them $(\mathrm{t}(123)=-0.46$, $\mathrm{p}=0.65)$. Moreover, although the MEDIU students' result had a higher mean than the IIUM students', these differences were not statistically significant.

Table 4. Descriptive statistics of the university differences in the three constructs

\begin{tabular}{|c|c|c|c|c|}
\hline & Mean & SD & $T$ & $p$-value \\
\hline \multicolumn{5}{|c|}{ First Construct: the benefits of reading stories in general life, or for language learning in particular } \\
\hline IIUM & 2.86 & 0.26 & -1.10 & 0.27 \\
\hline MEDIU & 2.90 & 0.20 & & \\
\hline \multicolumn{5}{|c|}{ Second Construct: visiting the library, and buying/exchanging stories } \\
\hline IIUM & 2.73 & 0.33 & -0.97 & 0.33 \\
\hline MEDIU & 2.79 & 0.29 & & \\
\hline \multicolumn{5}{|c|}{ Third Construct: reading stories and feeling pleasure in them } \\
\hline IIUM & 2.63 & 0.38 & -0.46 & 0.65 \\
\hline MEDIU & 2.67 & 0.39 & & \\
\hline
\end{tabular}

The results in Table 4 suggest that both universities, MEDIU and IIUM, located in the same environment, have students with similar interests and attitudes toward reading stories in Arabic. However, the higher mean for the MEDIU students may be due to their study mode, which is both online and on campus, meaning that these students had more access to stories and other material in both digital and hard copy format. 


\subsection{Gender differences between the three constructs}

The independent samples t-test showed no statistically significant gender differences for the three constructs: benefits of reading stories in general life and learning a language in particular ( $\mathrm{t}(118)=-$ $0.69, \mathrm{p}=0.50)$; visiting the library and buying and exchanging stories $(\mathrm{t}(117)=0.08, \mathrm{p}=0.94)$; and, reading stories and feeling pleasure in them $(\mathrm{t}(116)=-1.41, \mathrm{p}=0.16)$. Moreover, even though the female students had a slightly higher mean than the males, these differences were not statistically significant.

Table 5. Descriptive Statistics of the gender differences between the three constructs

\begin{tabular}{lcccc}
\hline \multicolumn{1}{c}{ Mean } & SD & $T$ & $p$-value \\
\hline First Construct: the benefits of reading stories & in & general life, or for language learning in particular \\
Male & 2.86 & 0.21 & -0.69 & 0.50 \\
Female & 2.89 & 0.24 & & \\
\hline Second Construct: visiting the library, and buying/exchanging stories & & \\
Male & 2.75 & 0.29 & 0.08 & 0.94 \\
Female & 2.75 & 0.32 & & \\
\hline Third Construct: reading stories and feeling pleasure in them & & \\
Male & 2.56 & 0.42 & -1.41 & 0.16 \\
Female & 2.67 & 0.37 & & \\
\hline
\end{tabular}

The two universities in the sample are co-educational. Despite the separate accommodation for males and females on campus, students have more opportunity to meet and exchange experiences, interests and attitudes to study and learning material. Table 5 indicates that these students liked studying Arabic and had strong motivation to do so. The females scored a slightly higher mean compared to the males, possibly because females in general consider reading as a daily routine (Mahakulkar \& Wanjari, 2014).

\subsection{Language differences between the three constructs}

The results of the independent samples t-test showed no statistically significant language differences between the three constructs: benefits of reading stories in general life and learning a language in particular ( $\mathrm{t}(111)=0.14, \mathrm{p}=0.89)$; visiting library and buying and exchanging stories $(\mathrm{t}(110)=0.36$, $\mathrm{p}=0.72)$; and, reading stories and feeling pleasure in them $(\mathrm{t}(109)=0.32, \mathrm{p}=0.75)$. Although the students who read short stories in their mother tongue had a higher mean than those who did not, these differences were not statistically significant.

Table 6. Descriptive statistics for the language differences between the three constructs

\begin{tabular}{lcccc}
\hline & Mean & SD & \multicolumn{1}{c}{$\boldsymbol{T}$} & $\boldsymbol{p}$-value \\
\hline First Construct: the benefits of reading stories in general life, or for language learning in particular \\
Read & 2.89 & 0.22 & 0.14 & 0.89 \\
Do not read & 2.87 & 0.36 & & \\
\hline Second Construct: visiting the library, and buying/exchanging stories & & \\
Read & 2.75 & 0.31 & 0.36 \\
Do not read & 2.72 & 0.40 & & \\
\hline Third Construct: reading stories and feeling pleasure in them & & & 0.72 \\
Read & 2.64 & 0.38 & 0.32 & \\
Do not read & 2.59 & 0.55 & & \\
\hline
\end{tabular}


The results for the language differences between the three constructs shown in Table 6 suggest that most of the native and NNSs' syllabuses depend on stories and dialogues, because of the features of the stories. Students therefore had opportunities to read stories in both their mother tongue and the L2. However, those who read short stories in their mother tongue had a higher mean, possibly because they read more short stories in this language and so were more familiar with stories compared to those who did not do so.

\subsection{Focus group results}

With regard to the types of short stories that the students preferred, the results from the focus group showed that comic stories were read most frequently ( $\mathrm{n}=28$ respondents), followed by fiction $(\mathrm{n}=19)$, adventure $(n=14)$, social and religious $(n=10)$, historical $(n=7)$, political $(n=5)$, and educational stories $(n=3)$. The popularity of comic stories may be because this type of story is joyful, interesting, and fun but still allows students to learn new words and phrases, as well as gaining life experience. The same also can be said of fiction stories, even though these stories are based on unreal people, places and events. Regarding adventure stories, this type differs from others because the suspense makes them more attractive for the reader, and this is in line with Sage's comment $(1987$, p.48) that "A good story is a joy". Fewer respondents selected the remaining story types (between 3-10 respondents), possibly because students do not find the same degree of fun and joy as in comic, fiction, and adventure stories.

\section{Conclusions}

This study investigated Arabic foreign language learners' attitudes to learning Arabic through short stories. A questionnaire was employed with 18 items distributed across three dimensions: benefits of reading stories in life in general, and language learning in particular; visiting the library and buying and exchanging stories; and, reading stories and feelings of pleasure in them. The questionnaire was conducted with 128 students studying at two universities: MEDIU and IIUM in Malaysia in the second semester of 2018/2019. The results showed that students had a positive attitude to reading short stories in the three dimensions. There were no statistically significant differences between the three variables of university, gender, and reading short stories in the mother tongue for the three dimensions. The results of the focus group revealed that the most popular types of story were comics, fiction, and adventures, and the least preferred were, in order, educational, political, and historical. The study therefore recommends the use of various types of story in the syllabus, and emphasizes the importance of including short stories in L2 Arabic syllabuses and texts.

\section{Ethics Committee Approval}

The author(s) confirm(s) that the study does not need ethics committee approval according to the research integrity rules in their country (Date of Confirmation: October 17, 2020).

\section{References}

Abidin, M. J. Z., Pour-Mohammadi, M., \& Alzwari, H. (2012). EFL students' attitudes towards learning English language: The case of Libyan secondary school students. Asian social science, 8(2), 119134.

Al-Dersi, Z. E. M. (2013). The use of short-stories for developing vocabulary of EFL learners. International Journal of English Language \& Translation Studies, 1(1), 72-86. 
Alexander, J. E., \& Filler, R. C. (1976). Attitudes and reading. Newark, DE: International Reading Association.

Ali, S. (1993). The reader-response approach: An alternative for teaching literature in a second language. Journal of Reading, 37(4), 288-296.

Al-Nassar, S. A., \& Salem, M. M., \& Abu Hashem, A. M. (2006). The motivation for reading and its relation to some personal and cognitive variables among middle school student. Faculty of Education Journal, Faculty of Education, Ain Shams University, 4(30), 129-198.

Altakhaineh, A. R. M., \& Zibin, A. (2017). The effect of incidental learning on the comprehension of English affixes by Arabic-speaking EFL learners: acquisition and application. Research in Language, 15(4), 405-423.

Amer, A. A. (2012). Using literature in reading English as second/foreign language. ERIC Collection (ED528593).

Bafile, C. (2003). Shared reading: Listening leads to fluency and understanding. Retrieved October 20, 2009, from http://www.educationworld.com/a_curr/profdev/profdev083.shtml

Baker, A., \& Grenn, E. (1977). Storytelling: Art and technique. New York, NY: R. R. Bowker.

Beck, I. L., \& McKeown, M. G. (2001). Text talk: Capturing the benefits of read-aloud experiences for young children. The Reading Teacher, 55(1), 10-19.

Biemiller, A., \& Boote, C. (2006). An effective method for building meaning vocabulary in primary grades. Journal of Educational Psychology, 98(1), 44-62.

Blachowicz, C. L. Z., \& Fisher, P. (2004). Vocabulary instruction. In B. J. Guzzetti (Ed.), Literacy in America: An encyclopaedia. Santa Barbara, CA: ABC-CLIO.

Collie, J., \& Slater, S. (1991). Literature in the language classroom. Cambridge: Cambridge University Press.

De Bot, K., Lowie, W., \& Verspoor, M. (2005). Second language acquisition: An advanced resource book. London: Routledge.

Dillard, M. (2005). Vocabulary instruction in the English classroom. Research Digest, 12, 21-29.

Dixon-Krauss, L. (2001). Using literature as a context for teaching vocabulary. Journal of Adolescent \& Adult Literacy, 45(4), 310-318.

Dolma, P. \& Boonprasitt, D. (2016). Short story reading as a means of enhancing vocabulary, using vocabulary self-collection strategy in English as a second language among seventh graders Bhutanese students. International Journal of Management and Applied Science, 2(12), 127-133.

Dornyei, Z. (2005). The psychology of the language learner: Individual differences in second language acquisition. Mahwah, NJ: Lawrence Erlbaum Associates.

Duff, A., \& Maley, A. (1990). Literature. Oxford University Press.

Ellis, R. (2000). Task-based research and language pedagogy. Language teaching research, 4(3), 193220.

Ghazali, S. N. (2008). Learner background and their attitudes towards studying literature. Malaysian Journal of ELT Research, 4(1),1-17.

Griva, E. (2007). A story-based framework for a primary school classroom. Retrieved July 06, 2009, from: http://exchanges.state.gov/forum/vols/vol45/no4/p26.htm. 
Heath, S. (1996). R-creating literature in the ESL classroom. TESOL Quarterly, 30(4), 776-778.

Hess, N. (2006). The short story: Integrating language skills through the parallel life approach. In A. Paran (Ed.), Literature in language teaching and learning (pp. 27-43). Alexandria, VA: Teachers of English to Speakers of Other Languages.

Holden, W. (2003). Student attitudes toward graded reading: A preliminary investigation. Bulletin of Hokuriku University, (27), 145-158.

İnal, H., \& Cakir, A. (2014). Story-based vocabulary teaching. Procedia-Social and Behavioural Sciences, (98), 675-679.

Justice, L. M., Meier, J., \& Walpole, S. (2005). Learning new words from storybooks: An efficacy study with at-risk kindergartners. Language, Speech \& Hearing Services in Schools, 36, 17-32.

Kim, M. (2004). Literature discussions in adult L2 learning. Language and Education, 18(2), 145-166.

Krashen, S. (2004). The power of reading. Portsmouth, NH: Heinemann Publishing Company.

Kuhn, M., \& Stahl, S. (1998). Teaching children to learn word meanings from context: A synthesis and some questions. Journal of Literacy Research, 30(1), 119-138.

Laine, E. (1997). 'The place of storytelling in language teaching'. In Falvey, P \& Kennedy, P (Eds.) Learning language through literature: A sourcebook for teachers of English in Hong Kong (pp. 6572). Hong Kong: Hong Kong University Press.

Lewis, D. (2009). Galaxy stress research. Mindlab International, Sussex University, UK.

Lihanda, M. K., \& Agufana, P. B. (2017). Attitude factors affecting teachers' use of short stories in the teaching of Kiswahili grammar in secondary schools in Nandi North Sub-County, Kenya. European Scientific Journal, 13(29), 172-183.

Mahakulkar, V., \& Wanjari, S. (2014). Gender wise comparative study of reading habit of bachelor education trainee teachers. International Journal of Education and Psychological Research (IJEPR), 3(3), 93-95.

Meyer, L. M. (2000). Barriers to meaningful instruction for English learners. Theory into practice, 39(4), 228-236.

Mohammadnejad, L. (2018). The effect of reading short stories on learning English collocations among pre-intermediate EFL learners. Journal of Sociological Research, 9(1), 102-116.

Montano, D. E., \& Kasprzyk, D. (2008). Theory of reasoned action, theory of planned behavior, and the integrated behavioral model. In K. Glanz, B. Rimer \& K. Viswanath (Eds.), Health behavior and health education: Theory, research, and practice (pp. 67-96). San Francisco, CA: Jossey-Bass.

Morrow, L. M. (2004). Motivation: The forgotten factor. Reading Today, 21(5), 6.

Musleh, O. A., \& Ahmed, I. S. (2010). The difficulties of the non-Arabic speakers in learning Arabic in (CELPAD): Students' perspective. Conference Paper presented to the National Conference PIMKU'2010, Malaysia, 23 to 25 June 2010.

Nash, H., \& Snowling, M. (2006). Teaching new words to children with poor existing vocabulary knowledge: A controlled evaluation of the definition and context methods. International Journal of Language and Communication Disorders, 41(3) 335-354.

Padwick, A. (2010). Attitudes towards English and varieties of English in globalizing India. University of Groningen. Newcastle, England. 
Reid, N. (2003). Getting started in pedagogical research in the physical sciences. LTSN Physical Sciences Centre, University of Hull, Hull.

Rezaei, S., \& Naghibian, M. (2018). Developing intercultural communicative competence through short stories: A qualitative inquiry. Iranian Journal of Language Teaching Research, 6(2), 77-96.

Rodrigo, V., Krashen, S., \& Gribbons, B. (2004). The effectiveness of two comprehensible-input approaches to foreign language instruction at the intermediate level. System, 32(1), 53-60.

Rosenkjar, P. (2006). Learning and teaching how a poem means: Literary stylistics for EFL undergraduates and language teachers in Japan. In A. Paran (Ed.), Literature in language teaching and learning (pp. 117-131). Alexandria, VA: Teachers of English to Speakers of Other Languages.

Sage, H. (1987). Incorporating literature in ESL instruction. Englewood Cliffs, NJ: Prentice-Hall.

Salem, M. M. (1996). Analytical study of students' reading tendency on secondary stage in the second half of the 20th century (Unpublished doctoral dissertation), Ain Shams University, Cairo, Egypt.

Shapiro, J. E. (1979). Developing an awareness of attitudes. In J. Shapiro (Ed.). Using literature and poetry effectively (pp. 2-7). Newark. DE: International Reading Association.

Tevdovska, E. S. (2016). Literature in ELT setting: Students' attitudes and preferences towards literary texts. Procedia-Social and Behavioral Sciences, 232, 161-169.

Visser, M. (2008). Learning under conditions of hierarchy and discipline: the case of the German Army, 1939-1940. Learning Inquiry, 2(2), 127-137.

Wang, J. H. Y., \& Guthrie, J. T. (2004). Modeling the effects of intrinsic motivation, extrinsic motivation, amount of reading, and past reading achievement on text comprehension between US and Chinese students. Reading Research Quarterly, 39(2), 162-186. 


\section{Anadili olmayanların dil derslerinde kısa Arapça hikayelerin kullanımına yönelik tutumları}

\section{$\ddot{\mathbf{O z}}$}

Bu çalışma, Arap olmayan öğrencilerin Malezya'daki üniversitelerde Arapça kısa öykü okumaya yönelik tutumlarını üç değişkene odaklanarak incelemeyi amaçlamaktadır: öğrencilerin üniversitesi, cinsiyeti ve ana dili. Bir anket ve 58 katılımcıyla yarı yapılandırılmış odak grup tartışması kullanılarak karma yöntem yaklaşımı kullanıldı. Çalışma, öğrencilerin kısa öykü okumaya karşı olumlu tutumları olduğunu ortaya çıkardı. Katılımcıların tutumları arasında üniversite türü, cinsiyet ve anadiline göre istatistiksel olarak anlamlı bir farklılık yoktur. Öğrencilerin tercih ettiği kısa öykü türlerine göre çizgi romanlar en çok öğrenciler tarafından okunmuştur. Son olarak, öğrenciler ayrıca Arapça dil becerilerini geliştirmek için kısa hikayeler kullanmayı çok teşvik edici ve destekleyici buldular.

Anahtar Sözcükler: dil öğretimi, kısa Arapça hikayeler, Arapça, Malezya

\section{AUTHOR BIODATA}

Omran Ahmad Musleh is an associate professor of Curriculum and Instruction Arabic language Al Ain University. He obtained his PhD in Curriculum and Instruction in Arabic Language from IIUM, Malaysia, 2013. His research interests are in Arabic Language, methods of teaching Arabic and Arabic Curricula for Native speakers and NonNative speakers. He has published several research papers in different journals e.g. Universal Journal of Educational Research, etc. ORCID: https://orcid.org/0000-0001-5411-5602

Mohamed Abdelrahman Ibrahim is an assistant professor of Arabic language and linguistics at International Islamic University Malaysia. He obtained his $\mathrm{PhD}$ in text linguistics from IIUM University, 2007. His research interests lie in the areas of analysis discourse and applied linguistics. He has published research papers in several journals, including: Al-Lisan International Journal, Journal of Linguistics and Literary Studies and Journal of Islam in Asia. ORCID: https://orcid.org/0000-0003-3851-1650

Abdel Rahman Mitib Altakhaineh is an assistant professor of English language and linguistics at The University of Jordan, Jordan. He obtained his PhD in linguistics from Newcastle University, UK, 2016. His research interests lie in the areas of morphology, lexical semantics, morphosyntax, applied linguistics, and psycholinguistics. He has published research papers in several journals, including: Studia Linguistica, Lingua, Acta Linguistica Hungarica, Metaphor and the Social World, Journal of Computer Assisted Learning, and Research in Language. ORCID: https://orcid.org/0000-0001-7605-2497 